\title{
Sedimentary petrology characteristics and their implications for provenance of Hoanh Bo Basin Neogene system in Quang Ninh province, north-eastern Vietnam
}

\author{
Hoang Van Tha ${ }^{1}$, Anna Wysocka ${ }^{2}$, \\ Nguyen Quoc Cuong ${ }^{1}$, Phan Dong Pha ${ }^{3}$, Piotr Ziółkowski ${ }^{2}$ \\ ${ }^{1)}$ Vietnam Academy of Sciences and Technology, Institute of Geological Sciences; 84 Chua Lang Str., Dong Da, Ha Noi, Vietnam; \\ e-mail: thahoangvan@gmail.com \\ 2) University of Warsaw, Faculty of Geology; ul. Żwirki i Wigury 93, Warsaw, Poland; e-mail: anna.wysocka@uw.edu.pl \\ ${ }^{3)}$ Vietnam Academy of Sciences and Technology, Institute of Marine Geology and Geophysics; 18 Hoang Quoc Viet Str., Cau Giay, \\ Ha Noi, Vietnam
}

(c) 2017 Authors. This is an open access publication, which can be used, distributed and reproduced in any medium according to the Creative Commons CC-BY 4.0 License requiring that the original work has been properly cited.

Received: 2017-03-01; accepted: 2017-04-28

\begin{abstract}
The Hoanh Bo Basin has developed over multiple periods since the Miocene period in association with the tectonic activity of the Chi Linh-Hon Gai and Trung Luong Faults. The basin is filled with Neogene continental sediments, comprising mainly polymictic conglomerates, sandstones, siltstones, claystones, and shales. Coarser-grained polymictic deposits predominate along the northern and western margins of the basin, whereas different types of siltstones, claystones, and sandstones occur in its centre, as well as along its southern and eastern parts, toward the Ha Long Bay. The conglomerates and sandstones are composed mainly of quartz and sedimentary rock fragments, and a small amount of mica. Cement is mainly built of iron-oxide, clay or carbonate mud. The source area for the Hoanh Bo Basin sediments was located in the close vicinity of the basin. It was built of strongly weathered rocks of the Hon Gai, Ha Coi, Cat Ba Formations.
\end{abstract}

Keywords: conglomerate, sandstone, petrography, Hoanh Bo Basin, Neogene, Vietnam

\section{INTRODUCTION}

The Hoanh Bo Basin is located within N $20^{\circ} 58^{\prime} 00^{\prime \prime}$ and $\mathrm{N} 21^{\circ} 06^{\prime} 00^{\prime \prime}$ latitude, E $106^{\circ} 58^{\prime} 00^{\prime \prime}$ and $\mathrm{E} 107^{\circ} 08^{\prime} 10^{\prime \prime}$ longitude, in the Quang Ninh province in north-eastern Vietnam (Fig. 1A, B). It is located close to the Ha Long Bay, and partly covered by a tidal flat area. Although it is close to the Bien Dong Sea (referred to as the South China Sea in English literature), it is surrounded by hilly and low-mountainous areas. Within the basin, the topographic surface is not flat and composed of hills with elevations up to a few tens of metres.
The Hoanh Bo Basin is one of the Tertiary basins that are related to the main fault zones of northern Vietnam. These basins are small, elongated, narrow grabens and half-graben. It has also been clearly understood that sedimentation in the Miocene basins displays a range of features indicative of tectonically-controlled basins (Wysocka \& Świerczewska 2005, 2010). Accordingly, the Hoanh Bo Basin has an almost trapezoidal form and is located between two active faults: the Chi Linh-Hon Gai and Trung Luong faults (Fig. 1C). Its basement is chiefly built of Triassic (Luong 1999, Ky 1999) and Jurassic rocks (Uy 1995). The Hon Gai Triassic 
coal and coal-bearing rocks crop out in some areas such as Le Loi and Thong Nhat (Fig. 1B). They have been an important source of coal for the industry for a long time. The basin is filled with Neogene and Quaternary sediments including breccias, conglomerates, sandstones, siltstones, claystones, and oil shales. The sediments reach a thickness of over 600 m (Luong 1999, Ky 1999). Presently, the Hoanh Bo Basin is a brachysyncline with a width of $7.5-8.0 \mathrm{~km}$ and a length of $12-13 \mathrm{~km}$.

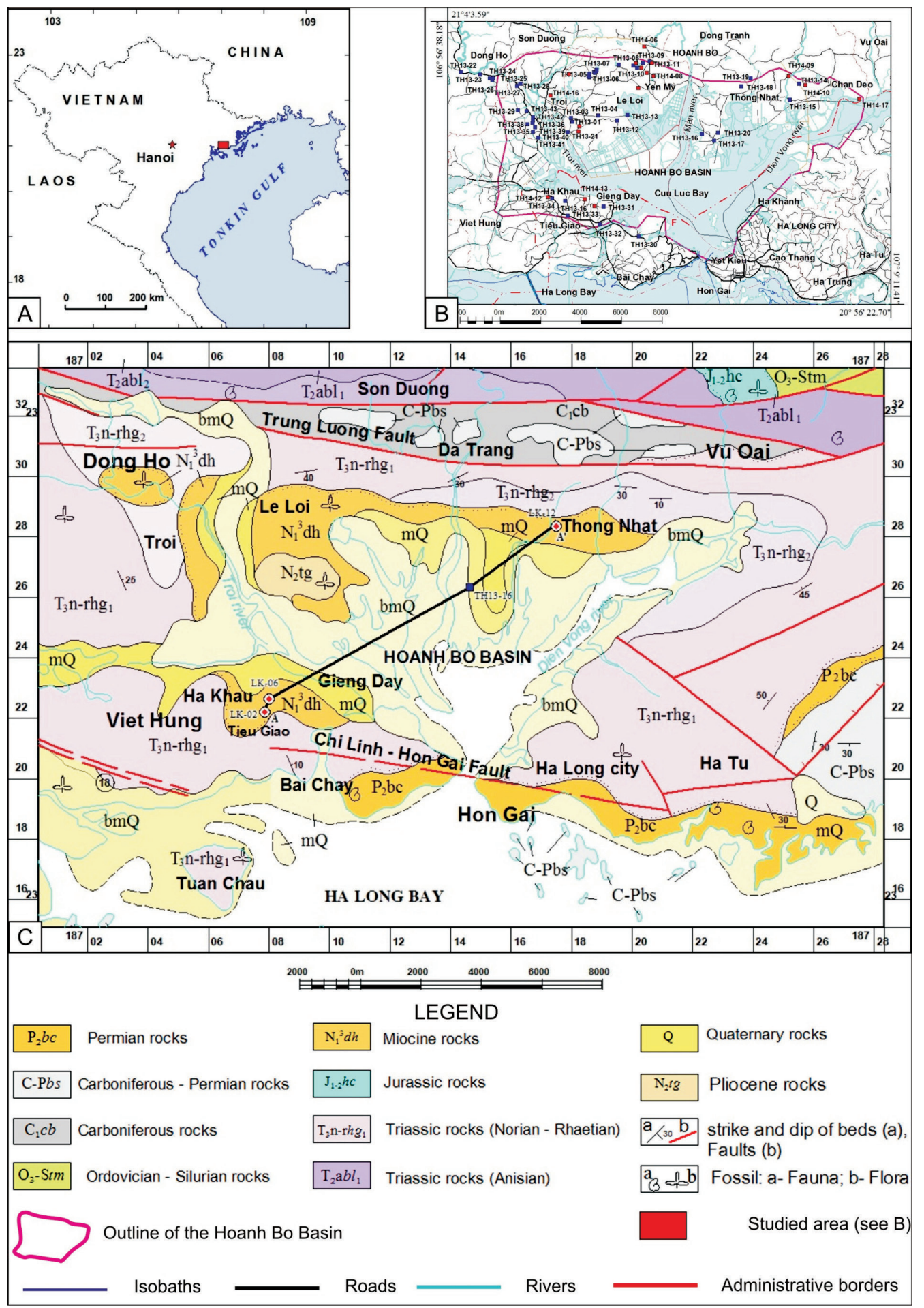

Fig. 1. Position of Vietnam in relation to adjacent countries (A); location of the Hoanh Bo Basin in the Quang Ninh province (according to the topographical map sheets of the General Administration of the Land of Vietnam, 2005) with the investigated exposures location (B); geological map of the study area (based on Luong 1999, Ky 1999) (C) 
The Hoanh Bo Basin is filled with siliciclastic sediments which were subdivided into the Dong Ho, Gieng Day and undivisional Quaternary Formations (Figs. 1C, 2). To date, the geological literature has treated the topic very generally. Based on the dominant grain size, the rocks infilling of the basin were assigned to conglomerates, sandstones, siltstones and claystones, in particular to oil shales, which have attracted many geologists (Patte 1927, Dovjikov et al. 1965, Quang 1969a \& 1969b, Nhan \& Danh 1975, Uy 1995, Luong 1999, Ky 1999, Trung et al. 1999, Tru et al. 2002). In spite of studies of lithostratigraphy, organic geochemistry and petrology of organic matter were available, but the coarse-grained rocks have been never studied in detail.

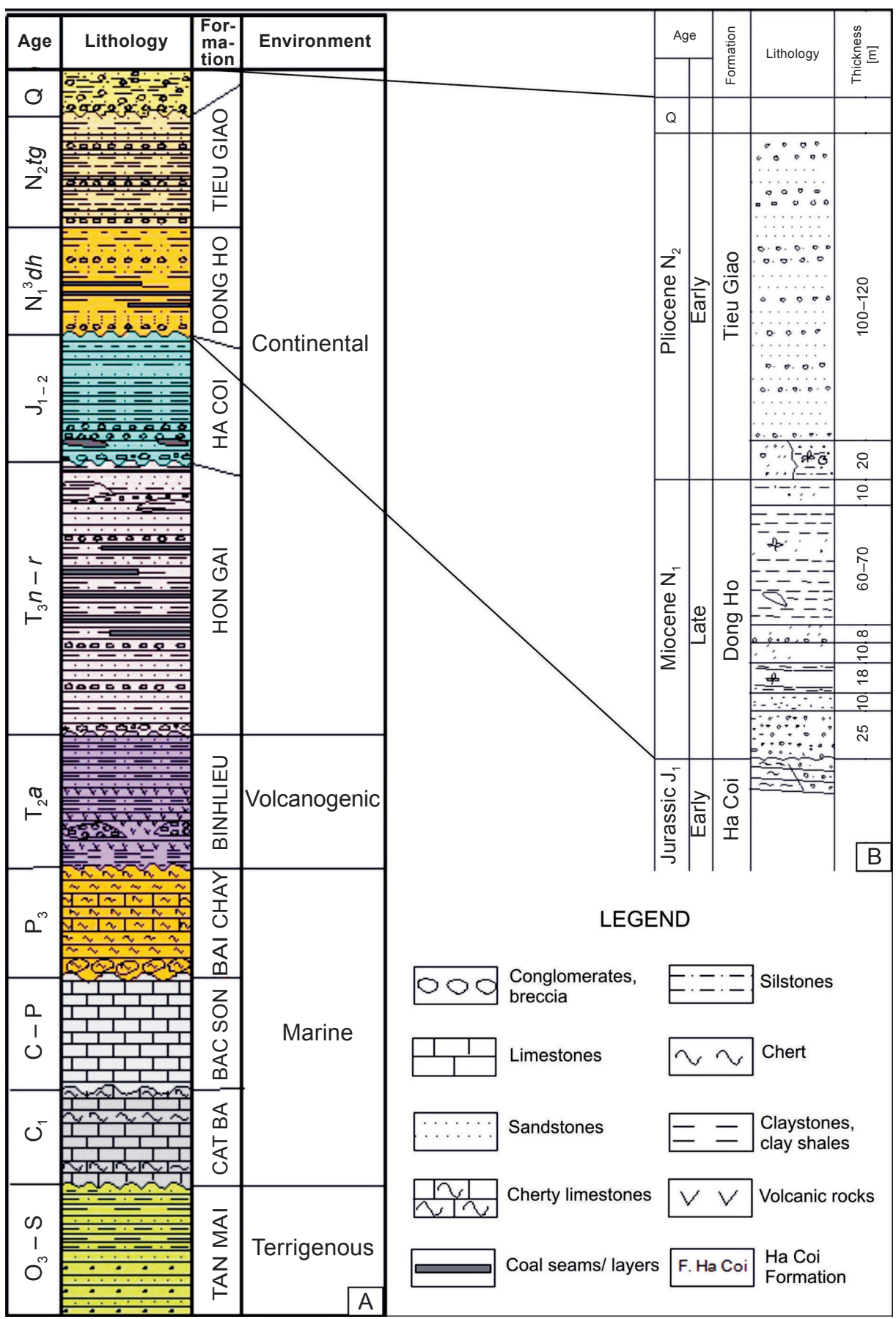

Fig. 2. Generalized stratigraphic column for the Hoanh Bo area (based on Nhan \& Danh 1975, Liem 1985, Khuc \& My 1988, Tuyen et al. 1995, Luong 1999, Khuc 2001 - simplified by Tha et al. 2014, 2015) (A); generalized stratigraphic column for Neogene basin infill (Thanh \& Khuc 1995, 2009) (B) 
Therefore, the goal of this study is to document conglomerates and sandstones petrographic features and interpret the provenace of sedimentary materials in the Hoanh Bo Basin, focussing on clast composition and grain-size characteristic. Petrological composition of rock plays an important role in geological interpretations. There have been many researches on the relationship between detrital composition of sandstone and tectonic settings of a provenace region (e.g. Dickinson \& Suczek 1979, Ingersoll \& Suczek 1979, Dickinson \& Valloni 1980, Valloni \& Mezzadri 1984, Pettijohn et al. 1987). Some works have shown that compositonal variations indicate a change of depostional environments and climate condition (Suttner 1974, Mack 1984), while others considered a change of composition connected with the role of relative sea-level fluctuation (Zuffa 1985, Morton et al. 1991, Johsson \& Basu 1993, Zuffa et al. 1995). In addition, the grain-size analysis is an useful tool not only for the classification of clastic deposits, but also for the interpretation of their depositional mechanisms and environments (Folk \& Ward 1957, Syvitski 1997, Sun et al. 2002, Torres et al. 2005).

\section{GEOLOGICAL SETTING}

The Hoanh Bo Basin is situated in the Quang Ninh sub-zone, which has the shape of a crescent embracing the An Chau Superimposed Depression to the north-northwest. Tri (1977) referred to this zone as the Quang Ninh Anticline Structure Zone. It is composed of volcano-clastic, terrigenous and carbonate rocks of Late Ordovician up to Late Palaeozoic in age (Fig. 1C). The thickness of this succession is about $3200 \mathrm{~m}$.

Mesozoic and Cenozoic coal-bearing deposits and mixed continental red beds fill up grabens and basins with thicknesses in the range from several hundreds to thousands of metres (e.g., Luong 1999, Ky 1999, Thanh \& Khuc 1995, 2009, Tha et al. 2015). Mesozoic sediments $\left(\mathrm{T}_{2}-\mathrm{J}_{1-2}\right)$ (Figs. 1C, 2) occur in narrow grabens. Most of the basement is built of the Hon Gai Formation ( $\mathrm{T}_{3} \mathrm{n}$-rhg), including quartz conglomerates, granule-size quartz gravelstones, thick-bedded sandstones interbedded with dark grey siltstones which contain coal seams, siltstones with lenses of claystones and coaly shales, thick coarse sandstones interbedded with conglomerates, granule-size gravelstones, siltstones, claystones and coal seams (Fig. 2). Moreover, in the area of Tieu Giao, Thong Nhat (for location see Fig. 1B) and in the north-eastern part of the basin, the Neogene rocks unconformably overlie Jurassic rocks of the Ha Coi Formation $\left(J_{1-2} h c\right)$ (Uy 1995).

In the Quang Ninh province, the Hoanh Bo Basin covers a modest area, with the width of 7.5$8.0 \mathrm{~km}$ and length of $12-13 \mathrm{~km}$ widening northwards (Tha et al. 2015). Basin lies between two major faults: the Chi Linh-Hon Gai Fault to the south and the Trung Luong Fault to the north (Fig. 1C).

The Hoanh Bo Basin is filled with deposits of the Dong Ho $\left(\mathrm{N}_{1}{ }^{3} t g\right)$ and Tieu Giao $\left(\mathrm{N}_{2} t g\right)$ formations (Figs. 1C, 2). The Dong Ho Formation $\left(\mathrm{N}_{1}^{3} t g\right)$ was originally defined by Nhan \& Danh (1975), and its type section is exposed along the Dong Ho stream and the Troi-Bang Be road. The lithostratigraphic succession of the Dong Ho Formation comprises 7 members (Fig. 2). They include: thickbedded grey conglomerates, sandstones, siltstones, oil-bearing shales, thin coal seams and thick-bedded claystones. The siltstones, claystones and oilbearing shales usually contain an assemblage of spores and pollen of Gleichenia sp., Quercus sp., Liquidambar sp., and leaf imprints of Pecopteris totangensis, Magnolia janschinii, and Laurus nobilis (Nhan \& Danh 1975). The total thickness of the formation ranges from $140 \mathrm{~m}$ to $418 \mathrm{~m}$ (Figs. 2, 3). The age of this formation is still under debate; however, most geologists consider it as Miocene. Trung et al. (1999) found an assemblage of flora and concluded that the Dong Ho deposits are of Oligocene age. Later, this opinion was confirmed by subsequent papers and published in various monographs (Thanh \& Khuc 2009, Tri \& Khuc 2009), but without strong evidence. However, in 2007, Prof. Wei Ming Wang from the Nanjing Institute of Geology and Palaeontology, Chinese Academy of Sciences, presented evidence on the Miocene age of the Dong Ho Formation based on the same samples (Huyen 2007). Moreover, finegrained rocks, rich in organic matter, were collected in 2013 (Tha et al. 2014, 2015). In only one sample, Prof. Ziembińska-Tworzydło of the Faculty of Geology, University of Warsaw, found an assemblage of Oligocene and Miocene flora. 


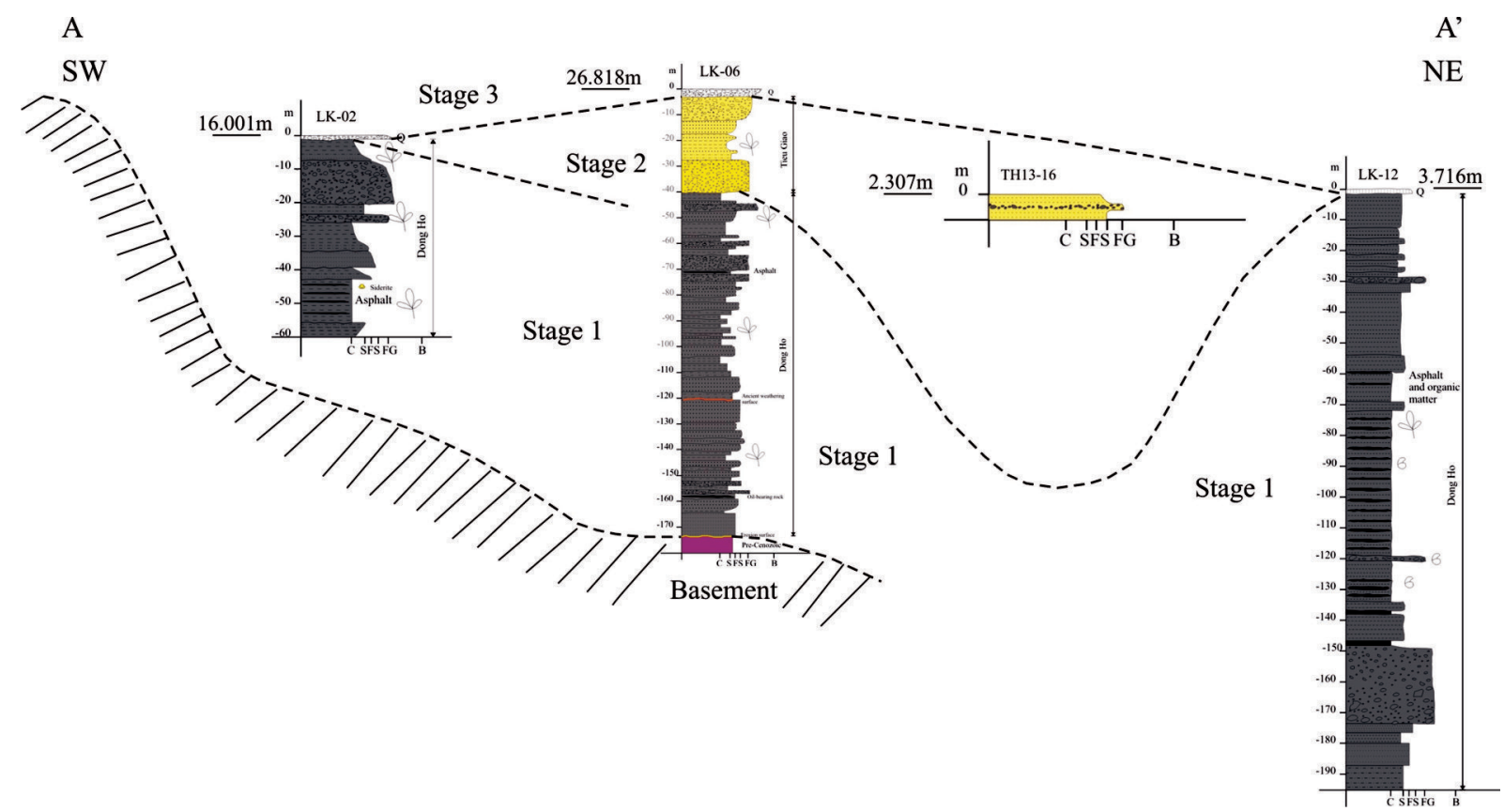

Fig. 3. Log correlation based on sedimentological features and published stratigraphic data (based on Tha 2016): grey - lacustrine and deltaic sediments; yellow - fluvial and aluvial fan sediments

By comparison with the floral assemblage from basins in southeast China, she concluded on the Miocene age of the strata involved. In her opinion, the Oligocene microflora in the discussed samples is redeposited. Based on the above statements, a Miocene age will be used in this report for the Dong Ho Formation.

The Tieu Giao Formation $\left(\mathrm{N}_{2} t g\right)$ consists of continental deposits with a limited occurrence in some small exposures in Tieu Giao, Xich Tho, and Troi (for location see Fig. 1B). The formation is built of weakly cemented conglomerates, gritstones and sandstones, and a few thin interbeds or lenses of ash grey argillaceous shales (Figs. 2, 3). The conglomerate pebbles are mainly composed of poorly rounded and angular quartzite and sandstone clasts. Plant remains were collected from the argillaceous shales, predominantly $\mathrm{Fa}$ gus sp. and Phoebe sp. (Fagus cf. stuxbergii - Phoebe pseudolanceolata assemblage) (Nhan \& Danh 1975, Dzanh 1995). The thickness of this formation varies from $120 \mathrm{~m}$ to $200 \mathrm{~m}$. According to Nhan \& Danh (1975), the collected flora belongs to the Phragmites oeningensis - Quercus neriifolia assemblage of Pliocene age. Quaternary unconsolidated deposits cover the central part of the basin and reach about 5-12 $\mathrm{m}$ in thickness.
Based on the author's sedimentological investigations (Tha et al. 2015, Tha 2016) seventeen sedimentary lithofacies were recognized in deposits filling the Hoanh Bo Basin. They were grouped into four facies associations representing four distinct terrestrial depositional environments. These comprise alluvial fan, fluvial, deltaic and lacustrine environments.

\section{MATERIALS AND METHODS}

In this study, we have just used the traditional methods in geology involving outcrop observation and laboratory investigation. Detailed geological investigations, section measurements, and sample collecting were performed in 2013 and 2014. The investigations were conducted in a total of 65 exposures (Fig. 1B). For conglomerate and breccias, sedimentological features such as clast composition, roundness, sorting, degree of sphericity, cement and matrix content were described and measured directly in the field (Tab. 1). For sandstones, 18 samples were selected for grain-size and petrographic analysis. 
Table 1

Petrographic composition of coarse-grained rocks from the Hoanh Bo Basin

\begin{tabular}{|c|c|c|c|c|c|c|}
\hline \multirow[b]{2}{*}{ Outcrop } & \multicolumn{3}{|c|}{ Total quantity (100\%) } & \multicolumn{2}{|c|}{ Clast $(100 \%)$} & \multirow[b]{2}{*}{ Rock name } \\
\hline & quartz & lithic clast & $\begin{array}{c}\text { matrix and } \\
\text { cement }\end{array}$ & quartz & lithic clast & \\
\hline \multirow{4}{*}{ TH13-03 } & 35.19 & 49.80 & 15.02 & 41.40 & 58.60 & MSC \\
\hline & 5.18 & 20.94 & 73.88 & 19.82 & 80.18 & MSC \\
\hline & 10.58 & 67.51 & 21.91 & 13.55 & 86.45 & MSC \\
\hline & 16.98 & 46.08 & 36.94 & 24.92 & 75.08 & 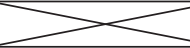 \\
\hline TH13-06 & 2.93 & 51.86 & 45.21 & 5.34 & 94.66 & MSC \\
\hline \multirow{3}{*}{ TH13-17 } & 5.37 & 58.72 & 35.91 & 8.38 & 91.62 & MSC \\
\hline & 4.45 & 63.77 & 31.78 & 6.52 & 93.48 & MSC \\
\hline & 4.91 & 61.25 & 33.84 & 7.45 & 92.55 & $3<$ \\
\hline \multirow{3}{*}{ TH13-28 } & 1.48 & 80.18 & 18.34 & 1.81 & 98.19 & MSB \\
\hline & 1.30 & 88.86 & 9.84 & 1.44 & 98.56 & $\mathrm{CSB}$ \\
\hline & 1.39 & 84.52 & 14.09 & 1.62 & 98.38 & $S$ \\
\hline \multirow{3}{*}{ TH13-36 } & 6.36 & 61.61 & 32.03 & 9.35 & 90.65 & MSC \\
\hline & 6.36 & 48.66 & 44.99 & 11.56 & 88.44 & MSC \\
\hline & 6.36 & 55.13 & 38.51 & 10.45 & 89.55 & 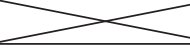 \\
\hline \multirow{4}{*}{ TH13-35 } & 21.53 & 63.74 & 14.73 & 25.25 & 74.75 & $\mathrm{CSC}$ \\
\hline & 16.05 & 63.95 & 20.00 & 20.07 & 79.93 & MSC \\
\hline & 11.49 & 60.88 & 27.63 & 15.88 & 84.12 & MSC \\
\hline & 16.36 & 62.86 & 20.79 & 20.40 & 79.60 & $S$ \\
\hline \multirow{7}{*}{ TH13-38 } & 0.26 & 93.77 & 5.97 & 0.28 & 99.72 & $\mathrm{CSC}$ \\
\hline & 0.24 & 85.65 & 14.11 & 0.28 & 99.72 & $\mathrm{CSC}$ \\
\hline & 0.88 & 44.74 & 54.39 & 1.92 & 98.08 & MSC \\
\hline & 24.61 & 65.10 & 10.28 & 29.05 & 70.95 & $\mathrm{CSC}$ \\
\hline & 15.06 & 73.01 & 11.92 & 17.10 & 82.90 & $\mathrm{CSC}$ \\
\hline & 9.40 & 61.54 & 29.06 & 13.25 & 86.75 & MSC \\
\hline & 8.41 & 70.64 & 20.96 & 10.31 & 89.69 & $S<$ \\
\hline \multirow{4}{*}{ TH13-39 } & 17.72 & 68.91 & 13.37 & 20.45 & 79.55 & $\mathrm{CSC}$ \\
\hline & 8.82 & 60.29 & 30.89 & 8.11 & 91.89 & MSC \\
\hline & 9.61 & 77.34 & 13.05 & 11.05 & 88.95 & $\mathrm{CSC}$ \\
\hline & 12.05 & 68.85 & 19.10 & 13.20 & 86.80 & 3 \\
\hline TH14-08 & 3.78 & 54.20 & 42.02 & 6.52 & 93.48 & MSC \\
\hline \multirow{3}{*}{ TH14-10 } & $<1.00$ & 83.30 & 16.70 & $<1.00$ & 100.00 & MSB \\
\hline & $<1.00$ & 88.46 & 11.54 & $<1.00$ & 100.00 & CSB \\
\hline & $<1.00$ & 85.88 & 14.12 & $<1.00$ & 100.00 & 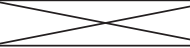 \\
\hline \multirow{3}{*}{ TH14-14 } & 1.15 & 79.50 & 19.35 & 1.43 & 98.57 & MSC \\
\hline & 1.25 & 75.19 & 23.56 & 1.64 & 98.36 & MSC \\
\hline & 1.20 & 77.34 & 21.45 & 1.53 & 98.47 & $\longrightarrow$ \\
\hline
\end{tabular}

Explanations: MSC - matrix-supported conglomerate; MSB - matrix-supported breccias; CSC - clast-supported conglomerate; CSB - clast-supported breccias; mean values are bolded

The grain-size analysis (Tab. 2) were carried out by the set of sieves (grain-size fractions at: $>2 \mathrm{~mm}$, 2-1 mm, 1-0.5 mm, 0.5-0.25 mm, 0.25-0.1 mm, $0.1-0.063 \mathrm{~mm}$ and $<0.063 \mathrm{~mm}$ ) in the Department of Sedimentology, Institute of Geological Sciences, Vietnam Academy of Science and Technology in Hanoi. Sedimentological parameters, such as median grain-size $(\mathrm{Md})$, mean grain-size $(\mathrm{M})$, degree of sorting (So), and skewness (Sk) were calculated based on the formulas of Folk and Ward (1957) (Tab. 3).

17 thin-sections were tested and described under a polarizing microscope at the Faculty of Geology, University of Warsaw (Tab. 4). 
Table 2

Grain-size analysis

\begin{tabular}{|l|c|c|c|c|c|c|c|c|c|c|}
\hline \multirow{2}{*}{ Samples } & \multicolumn{9}{|c|}{ Grain-size $[\mathbf{m m}]$} & \multicolumn{3}{c|}{ Parameters } \\
\cline { 2 - 11 } & $>\mathbf{1 . 0}$ & $\mathbf{1 . 0 - 0 . 5}$ & $\begin{array}{c}\mathbf{0 . 5}- \\
\mathbf{0 . 2 5}\end{array}$ & $\begin{array}{c}\mathbf{0 . 2 5 -} \\
\mathbf{0 . 1}\end{array}$ & $\begin{array}{c}\mathbf{0 . 1}- \\
\mathbf{0 . 0 6 3}\end{array}$ & $<\mathbf{0 . 0 6 3}$ & $\mathbf{M d}$ & $\mathbf{M}$ & $\mathbf{6}$ & Sk \\
\hline TH13-03/1 & 1.50 & 4.20 & 47.30 & 33.30 & 2.30 & 11.40 & 0.261 & 0.27 & 0.16 & 0.09 \\
\hline TH13-05 & 24.00 & 37.40 & 25.10 & 7.20 & 2.20 & 4.10 & 0.624 & 0.69 & 0.44 & 0.20 \\
\hline TH13-06/2 & 42.50 & 21.30 & 19.70 & 6.90 & 1.30 & 8.30 & 0.867 & 0.82 & 0.51 & -0.12 \\
\hline TH13-09B/0 & 38.40 & 29.20 & 33.80 & 29.60 & 7.60 & 11.40 & 0.424 & 0.62 & 0.51 & 0.46 \\
\hline TH13-13/1 & 13.40 & 34.70 & 25.70 & 12.00 & 3.60 & 10.60 & 0.481 & 0.52 & 0.39 & 0.22 \\
\hline TH13-13/3-1 & 0.20 & 8.90 & 64.50 & 18.80 & 2.30 & 5.30 & 0.322 & 0.30 & 0.18 & -0.01 \\
\hline TH13-13/3-2 & 0.00 & 2.20 & 42.10 & 40.40 & 4.80 & 10.50 & 0.229 & 0.24 & 0.14 & 0.08 \\
\hline TH13-17/3 & 1.10 & 12.40 & 42.90 & 22.40 & 4.00 & 17.20 & 0.279 & 0.27 & 0.21 & 0.05 \\
\hline TH13-21 & 11.70 & 13.60 & 34.00 & 33.80 & 6.90 & 0.00 & 0.298 & 0.41 & 0.35 & 0.58 \\
\hline TH13-21/5-3 & 1.00 & 14.80 & 27.60 & 24.70 & 11.00 & 20.90 & 0.205 & 0.28 & 0.26 & 0.40 \\
\hline TH13-21/5-4 & 0.00 & 1.80 & 15.30 & 49.60 & 17.70 & 15.60 & 0.136 & 0.14 & 0.10 & 0.23 \\
\hline TH13-21/6-2 & 3.20 & 45.50 & 22.70 & 13.50 & 4.70 & 10.40 & 0.489 & 0.37 & 0.25 & -0.47 \\
\hline TH13-21/6-3 & 10.60 & 36.70 & 38.30 & 8.00 & 2.10 & 4.30 & 0.479 & 0.54 & 0.32 & 0.24 \\
\hline TH13-21/8-1 & 10.00 & 33.30 & 22.10 & 13.60 & 5.70 & 15.30 & 0.426 & 0.46 & 0.38 & 0.20 \\
\hline TH13-24-1 & 21.80 & 15.20 & 16.50 & 11.40 & 4.10 & 31.00 & 0.292 & 0.49 & 0.50 & 0.55 \\
\hline TH13-32/2 & 65.50 & 9.50 & 8.60 & 6.10 & 2.00 & 8.30 & 1.162 & 0.92 & 0.52 & -0.53 \\
\hline TH13-33 & 13.40 & 30.10 & 22.00 & 15.40 & 6.20 & 12.90 & 0.423 & 0.49 & 0.41 & 0.27 \\
\hline TH13-34 & 81.30 & 12.90 & 14.80 & 20.70 & 5.10 & 15.20 & 1.057 & 0.87 & 0.55 & -0.40 \\
\hline
\end{tabular}

Explanations: Md - median; M - mean; 6 - standard deviation; Sk - skewness

Table 3

Parameters of grain-size distribution

\begin{tabular}{|c|c|c|c|c|c|c|c|c|}
\hline \multirow{2}{*}{ Samples } & \multicolumn{5}{|c|}{ Parameters } & \multirow{2}{*}{$\begin{array}{l}\text { Grain-size } \\
\text { distribution }\end{array}$} & \multirow{2}{*}{ Sorting } & \multirow{2}{*}{ Skewness } \\
\hline & $\varphi 95$ & $\varphi 84$ & $\varphi 50$ & $\varphi 16$ & $\varphi 5$ & & & \\
\hline TH13-03/1 & 0.56 & 0.43 & 0.261 & 0.12 & 0.0075 & monomodal & VWS & near symmetrical \\
\hline TH13-05 & 1.4 & 1.2 & 0.624 & 0.26 & 0.076 & monomodal & WS & fine skewed \\
\hline TH13-06/2 & 1.56 & 1.35 & 0.867 & 0.235 & 0.02 & polymodal & MWS & near symmetrical \\
\hline TH13-09B/0 & 1.46 & 1.3 & 0.424 & 0.125 & 0.01 & bimodal & MWS & strongly fine skewed \\
\hline TH13-13/1 & 1.28 & 0.95 & 0.481 & 0.125 & 0.06 & bimodal & WS & fine skewed \\
\hline TH13-13/3-1 & 0.7 & 0.45 & 0.322 & 0.14 & 0.04 & monomodal & VWS & near symmetrical \\
\hline TH13-13/3-2 & 0.46 & 0.39 & 0.229 & 0.1 & 0.02 & monomodal & VWS & near symmetrical \\
\hline TH13-17/3 & 0.63 & 0.495 & 0.279 & 0.05 & 0.0088 & polymodal & VWS & near symmetrical \\
\hline TH13-21 & 1.29 & 0.8 & 0.298 & 0.132 & 0.09 & bimodal & WS & strongly fine skewed \\
\hline TH13-21/5-3 & 0.732 & 0.6 & 0.205 & 0.02 & 0.002 & bimodal & VWS & strongly fine skewed \\
\hline TH13-21/5-4 & 0.4 & 0.232 & 0.136 & 0.063 & 0.003 & monomodal & VWS & fine skewed \\
\hline TH13-21/6-2 & 0.985 & 0.5 & 0.489 & 0.109 & 0.0054 & monomodal & VWS & strongly coarse-skewed \\
\hline TH13-21/6-3 & 1.095 & 0.885 & 0.479 & 0.245 & 0.07 & monomodal & VWS & fine skewed \\
\hline TH13-21/8-1 & 1.17 & 0.89 & 0.426 & 0.068 & 0.003 & bimodal & WS & fine skewed \\
\hline TH13-24/1 & 1.35 & 1.18 & 0.292 & 0.0125 & 0.003 & polymodal & WS & strongly fine skewed \\
\hline TH13-32/2 & 1.59 & 1.38 & 1.162 & 0.232 & 0.049 & polymodal & MWS & strongly coarse-skewed \\
\hline TH13-33 & 1.23 & 0.97 & 0.423 & 0.08 & 0.004 & bimodal & WS & fine skewed \\
\hline TH13-34 & 1.54 & 1.42 & 1.057 & 0.12 & 0.0222 & bimodal & MWS & strongly coarse-skewed \\
\hline
\end{tabular}

Explanations: VWS - very well sorted; WS - well sorted; MWS - moderately well sorted 
Table 4

Thin-sections analysis

\begin{tabular}{|c|c|c|c|c|c|c|c|c|c|c|c|}
\hline \multirow[b]{2}{*}{ Samples } & \multicolumn{6}{|c|}{ Grain composition [\%] } & \multicolumn{3}{|c|}{ Clast (100\%) } & \multirow[b]{2}{*}{ Classification } & \multirow[b]{2}{*}{ Age } \\
\hline & quartz & $\mathbf{F}$ & LC & mica & others & $\begin{array}{l}\text { matrix } \\
+ \text { cem. }\end{array}$ & $\begin{array}{c}\mathbf{Q}+ \\
\mathbf{M}+ \\
\text { others }\end{array}$ & $\mathbf{F}$ & LC & & \\
\hline \multicolumn{12}{|c|}{ Troi } \\
\hline TH13-37/1 & 32.54 & 0.00 & 0.96 & 0.00 & 0.00 & 66.50 & 97.13 & 0 & 2.87 & quartz wacke & $\mathrm{T}$ \\
\hline TH13-43/1 & 44.77 & 0.00 & 1.14 & 0.00 & 0.00 & 54.09 & 97.52 & 0 & 2.48 & quartz wacke & $\mathrm{N}$ \\
\hline \multicolumn{12}{|c|}{ Le Loi } \\
\hline TH13-06A/2 & 34.86 & 0.00 & 7.80 & 0.00 & 0.00 & 57.34 & 81.72 & 0 & 18.28 & lithic wacke & $\mathrm{N}$ \\
\hline TH13-13A & 39.64 & 0.00 & 21.48 & 0.00 & 0.00 & 38.88 & 64.86 & 0 & 35.14 & lithic wacke & $\mathrm{N}$ \\
\hline TH13-09A/2 & 50.25 & 0.00 & 5.56 & 0.00 & 3.28 & 40.91 & 90.59 & 0 & 9.41 & lithic wacke & $\mathrm{N}$ \\
\hline TH13-09B/5 & 8.37 & 0.00 & 0.00 & 0.00 & 0.00 & 91.63 & 100 & 0 & 0 & quartz wacke & $\mathrm{N}$ \\
\hline TH13-21/5-1 & 33.47 & 0.00 & 1.67 & 0.25 & 0.49 & 64.12 & 95.35 & 0 & 4.65 & quartz wacke & $\mathrm{N}$ \\
\hline TH13-21/5-2 & 49.76 & 0.00 & 30.18 & 0.00 & 0.00 & 20.07 & 62.25 & 0 & 37.75 & lithic wacke & $\mathrm{N}$ \\
\hline TH13-21/6-8 & 49.98 & 0.00 & 1.52 & 0.00 & 0.00 & 48.50 & 97.05 & 0 & 2.95 & quartz wacke & $\mathrm{N}$ \\
\hline TH13-21/6-5 & 48.32 & 0.00 & 22.35 & 3.63 & 3.63 & 22.07 & 71.32 & 0 & 28.68 & lithic wacke & $\mathrm{N}$ \\
\hline TH13-21/8-3 & 63.92 & 0.00 & 1.10 & 0.00 & 0.00 & 34.98 & 98.31 & 0 & 1.69 & quartz wacke & $\mathrm{N}$ \\
\hline \multicolumn{12}{|c|}{ Thong Nhat } \\
\hline TH13-17/2 & 43.81 & 0.00 & 35.23 & 0.00 & 0.18 & 20.78 & 55.53 & 0 & 44.47 & lithic wacke & $\mathrm{N}$ \\
\hline TH13-19 & 69.56 & 0.00 & 20.23 & 0.18 & 0.45 & 9.58 & 77.63 & 0 & 22.37 & sublitharenite & $\mathrm{T}$ \\
\hline \multicolumn{12}{|l|}{ Ha Khau } \\
\hline TH13-33/5 & 66.98 & 0.00 & 2.87 & 0.96 & 0.00 & 29.19 & 95.95 & 0 & 4.05 & quartz wacke & $\mathrm{N}$ \\
\hline \multicolumn{12}{|c|}{ Dong Ho } \\
\hline TH13-22 & 45.77 & 0.00 & 32.21 & 0.00 & 0.00 & 22.02 & 58.69 & 0 & 41.31 & lithic wacke & $\mathrm{T}$ \\
\hline TH13-25/2 & 31.41 & 0.00 & 0.00 & 0.00 & 0.00 & 68.59 & 100 & 0 & 0 & quartz wacke & $\mathrm{N}$ \\
\hline TH13-26 & 18.39 & 0.00 & 57.31 & 0.00 & 0.00 & 24.30 & 24.29 & 0 & 75.71 & lithic wacke & $\mathrm{N}$ \\
\hline
\end{tabular}

Explanations: F - feldspar; LC - lithic clast ; Q - quartz; M - mica; N - Neogene; T - Triassic

\section{RESULTS}

\section{Texture and petrographic composition of breccias and conglomerates}

Different kinds of conglomerates and breccias are very common in the study area and crop out in many exposures. They are concentrated in the basal part of the formation and along the northern margin of the basin. Based on fabric analysis (Tab. 1), they were sub-divided into two general groups: clast-supported conglomerates and breccias (Fig. 4) and matrix-supported conglomerates and breccias (Fig. 7).

In the study area, clast-supported conglomerates and breccias (Fig. 4) are rather weakly cemented, only in the Le Loi section they are occasionally strongly lithified. The colour of the conglomerates is variable, from red, reddish brown, grey, to white grey. The clasts are very angular- to angular (breccias), and rounded to well-rounded, occasionally sub-angular (conglomerates). The grain size of the clasts ranges from granule- to cobblesized, occasionally boulder-sized. The shape of the clasts is commonly bladed and prolate, equant. They are poorly to moderately sorted, occasionally well sorted.

The clast-supported breccias and conglomerates have a rather simple composition, including quartz (0.0-24.61\%; averagely 9.08\%), sedimentary clasts (63.74-93.77\%; averagely $79.49 \%$ ), matrix and cement (5.97-14.73\%; averagely 11.43\%) in bulk samples. The total quantity of quartz ranges from $0.00 \%$ to $29.05 \%$ (averagely $10.56 \%$ ) and that of clasts ranges from $70.95 \%$ to $99.72 \%$ (averagely 89.44\%) (Tab. 1, Fig. 5A).

Sedimentary clasts include conglomerates, sandstones, mudstones and limestones (Fig. 6A-H). Limestone clasts are present in small amounts. The 
matrix is very rich in quartz grains but there are also other components, such as silty matrix. The cement is siliceous and ferruginous. Rocks in the lower part of the Dong Ho Formation are dominated by ferruginous cement. The upper part is commonly developed as siliceous cement.

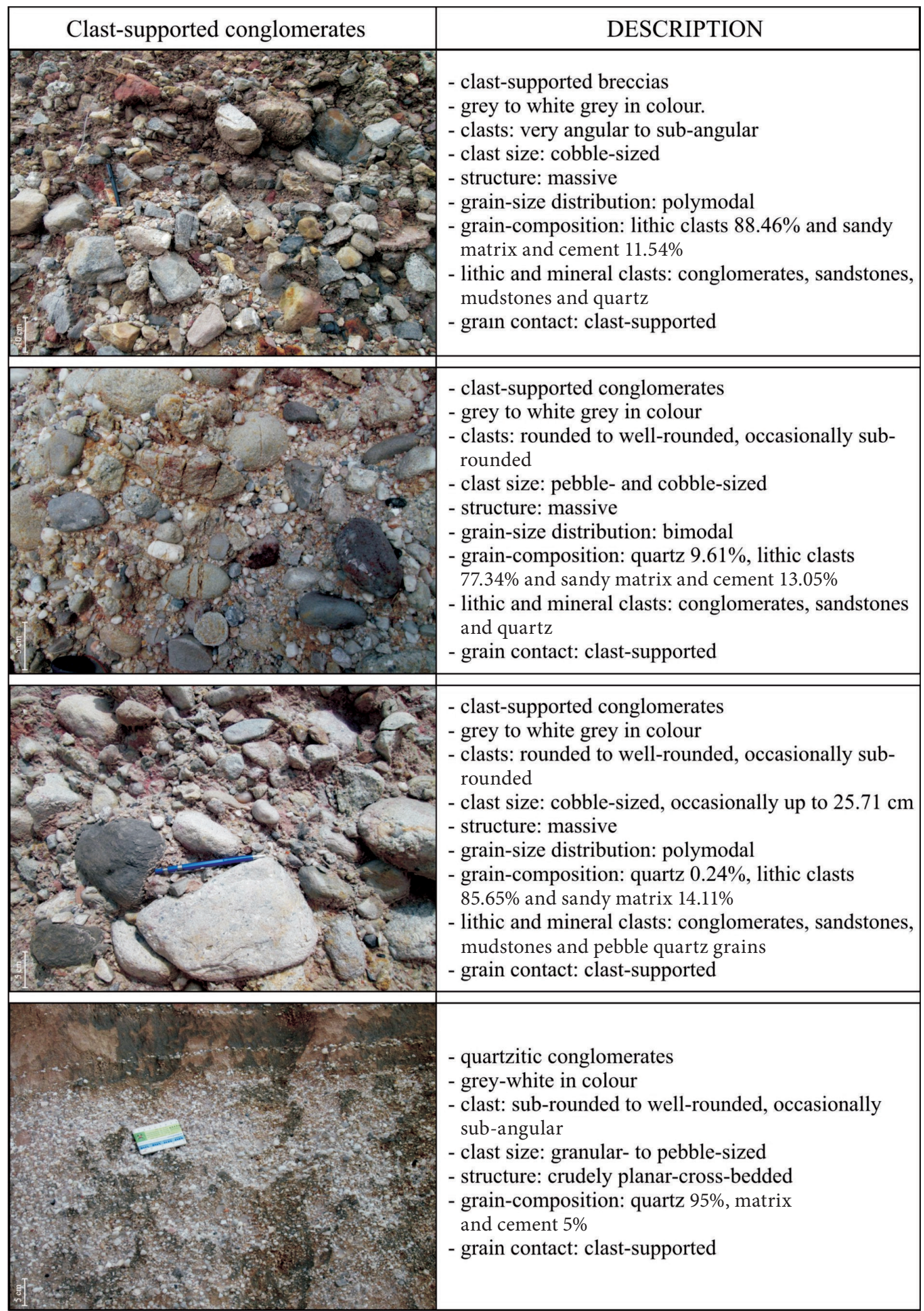

Fig. 4. Characteristics of the clast-supported conglomerates and breccias 

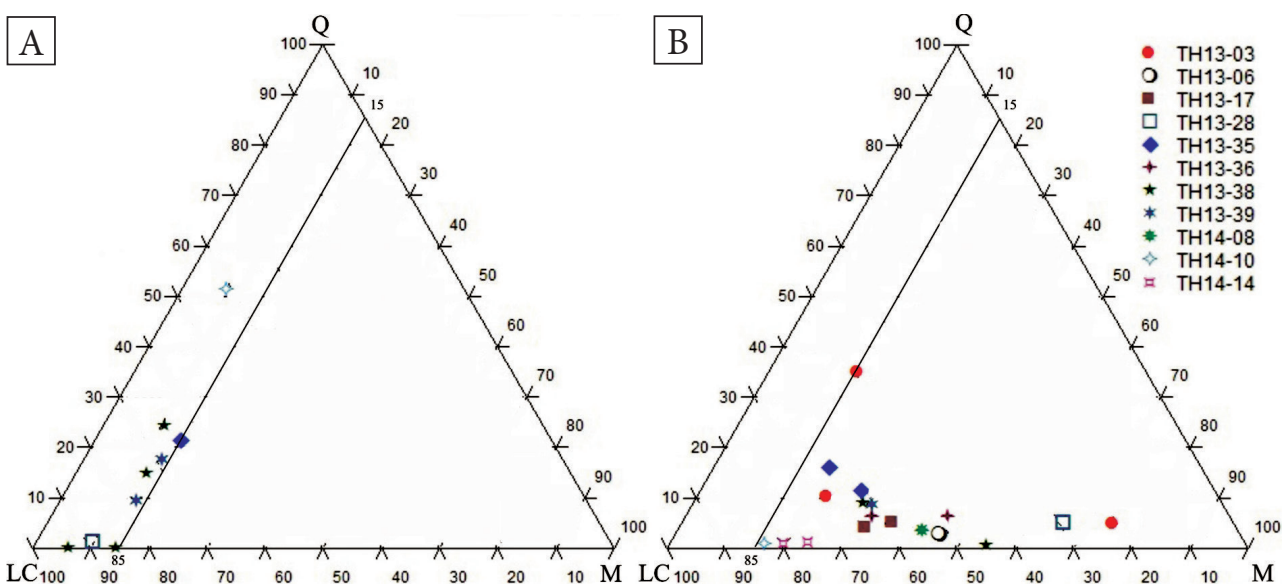

Fig. 5. Petrographic composition of clast-supported conglomerates and breccias (A) and matrix-supported conglomerates and breccias (B); $Q$ - quartz, $L C$ - lithic clast, $M$ - matrix and cement
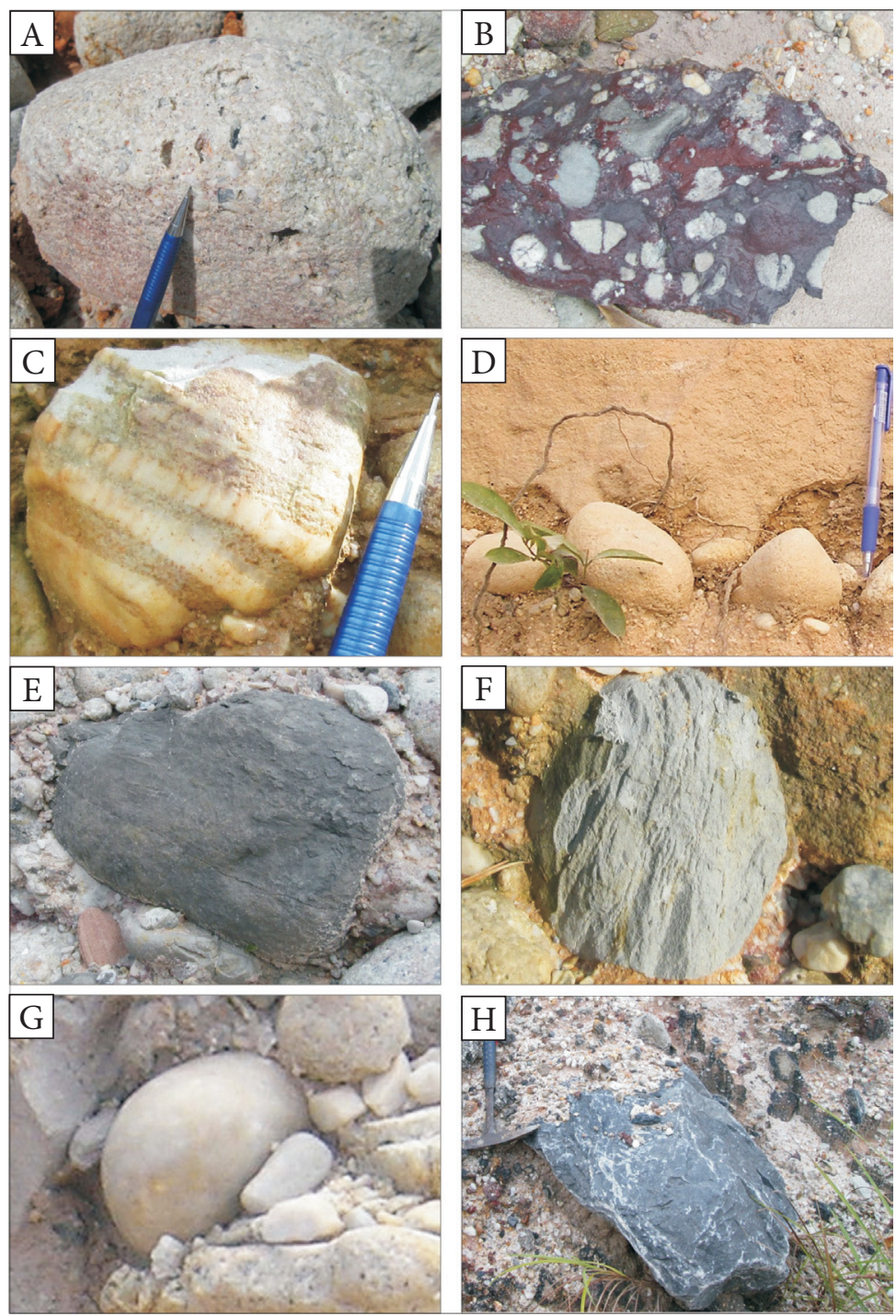

Fig. 6. Lithic clasts typical for coarse-grained deposits of the Hoanh Bo Basin: clast of conglomerate with siliceous and ferruginous cement (TH13-38) (A); clast of conglomerate with ferruginous cement (TH13-38) (B); clast of sandstone with quartz veins $(5.82 \mathrm{~cm})($ TH13-36) (C); clast of sandstone-lag deposits (photo by Pha P.D.) (D); clast of mudstone rich in organic matter (TH1338) (E); clast of mudstone poor in organic matter (TH13-35) (F); well rounded quartz clasts (3.72 cm) (Pha P.D.) (G); clasts of limestone (TH13-09) (H) 


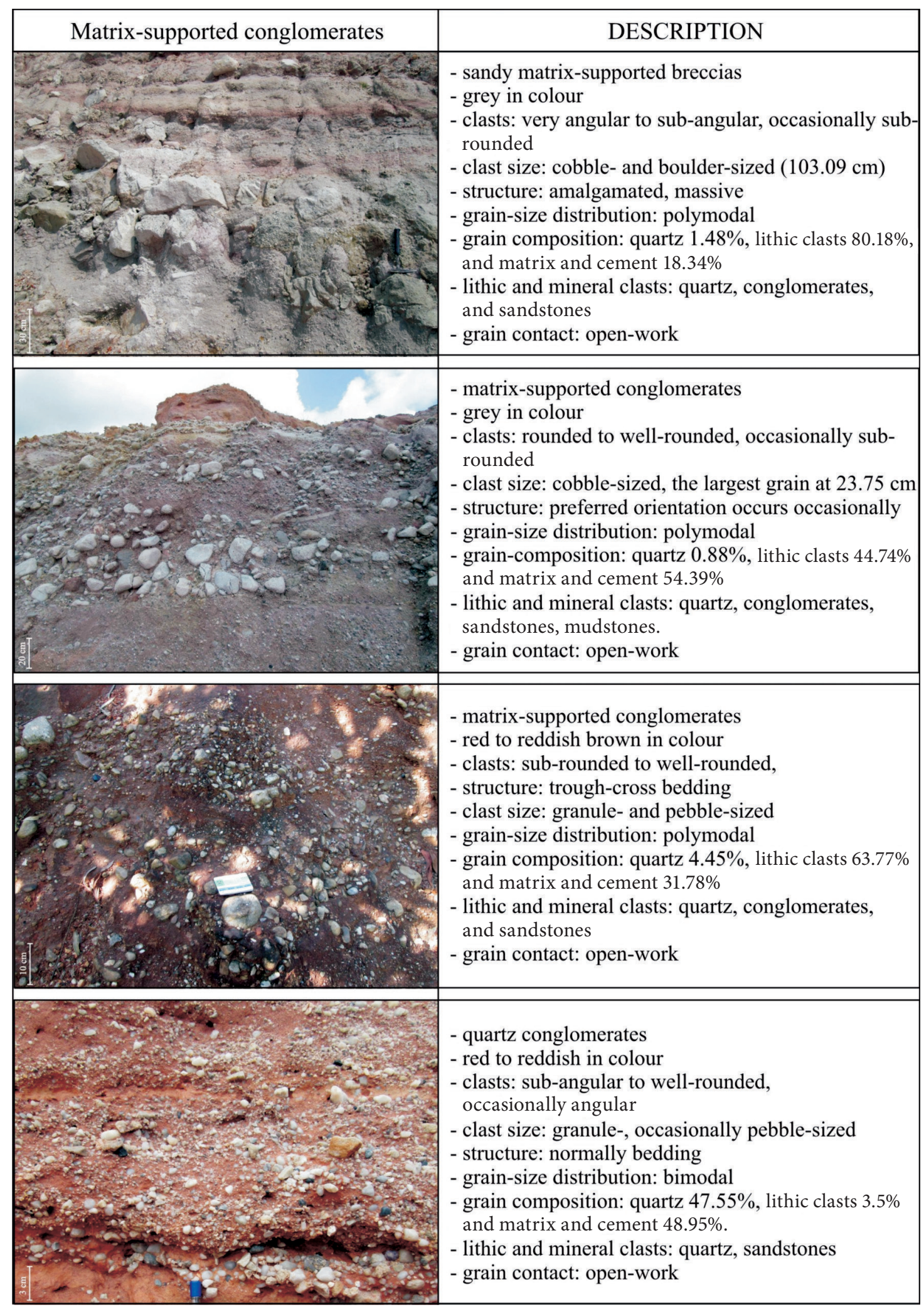

Fig. 7. Characteristics of matrix-supported conglomerates and breccias

The matrix-supported conglomerates and breccias (Fig. 7) usually occur together with the clast-supported conglomerates in all conglomerate exposures. In the study area, the presence of these rocks is more common than of the clast-supported conglomerates. The grain size of the clasts ranges 
commonly from granule- to cobble-sized (Fig. 7); occasionally boulders with sizes up to $103.09 \mathrm{~cm}$ are present. The shape of the clasts is commonly bladed and prolate, similarly as in the clast-supported conglomerates. They are poorly to moderately sorted or even unsorted. The grain-size distribution is bimodal and polymodal. Sandy matrix is rich in quartz grains. The clasts are not in contact with each other, floated in matrix and cement.

The matrix-supported conglomerates are rather unimodal in composition, including quartz (0.0-47.55\%; averagely $9.80 \%)$, sedimentary lithic clasts (3.50-83.30\%; averagely 57.65\%), matrix and cement (15.02-73.88\%; averagely $32.55 \%)$ in the bulk samples. Quartz ranges from $0.00 \%$ to 93.15\% (averagely $15.16 \%$ ) and lithic clasts are in the range of $0.00-100 \%$ (averagely $84.48 \%$ ) (Tab. 1, Fig. 5B). In general, the content of the quartz in the clast-supported conglomerates is relatively smaller than in the matrix-supported conglomerates; conversely, the content of sedimentary fragments in the clast-supported conglomerates is higher.

The other lithic clasts are largely sedimentary rocks comprising conglomerates, sandstones, and mudstones (Fig. 6). Clasts are typically glued together by a small amount of siliceous or ferruginous cement, whereas calcareous cement is not present. The matrix is an assemblage of poorly sorted sand and mud. Similarly to the clast-supported conglomerates, the matrix-supported conglomerates predominate in the lower part of the Dong Ho Formation.

\section{Texture and petrographic composition of sandstones}

The results of the grain-size analysis are shown in Tables 2 and 3. The mean grain-size (M) of all samples ranges in an interval of $0.145-0.925 \mathrm{~mm}$ and points to the sand fraction. The value 6 (standard deviation) ranges from 0.102 to 0.555 and points to very well sorted to moderately well sorted deposits. The value Sk (skewness) ranges from -0.53 to 0.58 . The grain-size distribution shows monomodal, bimodal and polymodal grain-size distributions (Fig. 8). The content of the fine-grained fraction ranges from a very small amount up to $31 \%$. Moreover, thirteen samples of Neogene rocks were analyzed in thin sections under a polarized light microscope. Four types of detrital grains were recognized: quartz, mica, rock fragments and other minerals (Tab. 4, Fig. 9). No feldspar grains were encountered in these thin sections.
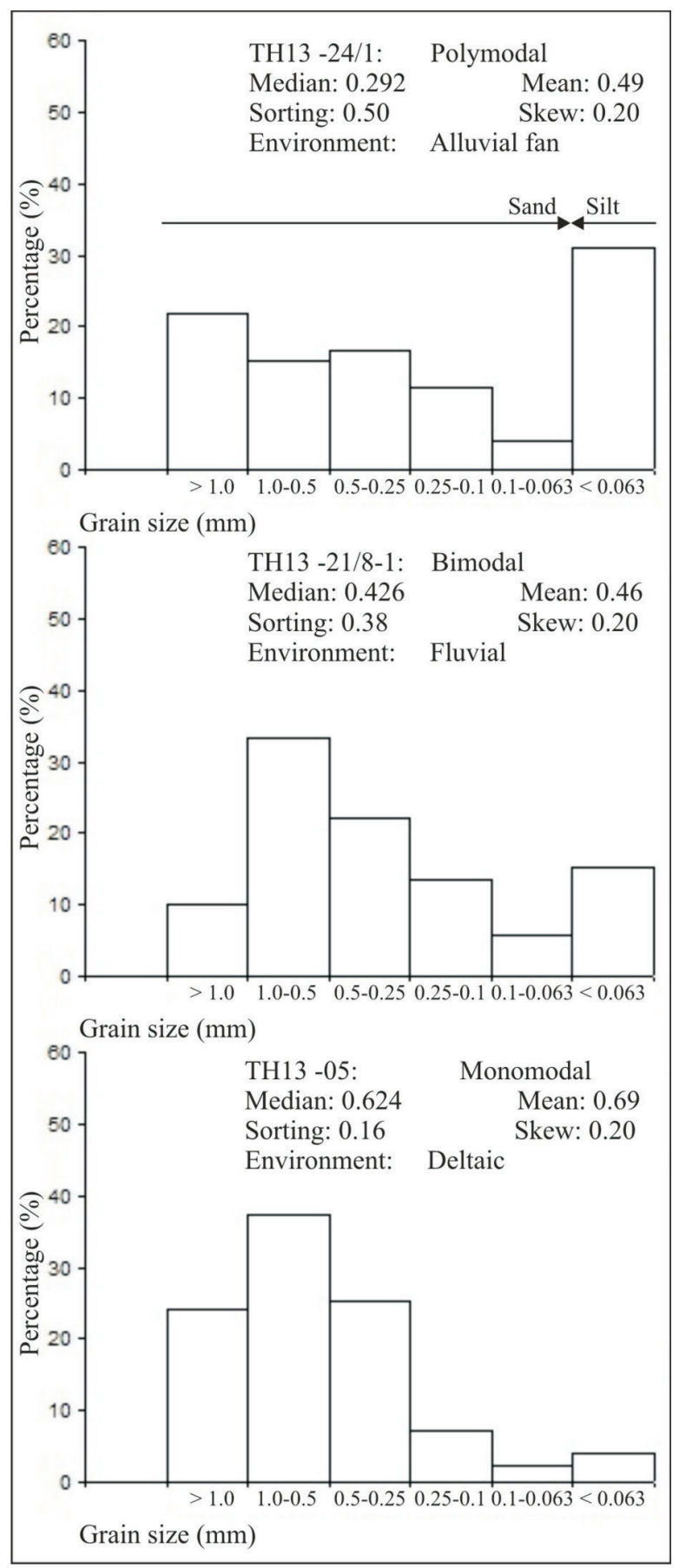

Fig. 8. Histogram of grain-size distribution

Quartz is the major component of the sediments with an extremely wide grain-size range in the study area. The quartz content ranges from about $18.39 \%$ to $66.98 \%$. On the contrary, 
feldspar is completely absent in all thin sections. The quartz grains are mono- and polycrystalline (Figs. 10A-C, F, G, 11A, F). They are typically white in colour and extinguish light uniformly under crossed polars, sometimes with undulose extinction. They are frequently very angular and sub-rounded, occasionally well rounded. Quartz grains are strongly fractured in many different directions. They were probably derived from rocks of the Hon Gai and Ha Coi formations. In addition, they build almost unconsolidated monomineral bodies, such as in exposures TH13-21 (Le Loi), TH13-05 (Le Loi), and TH13-04 (Troi).

The content of rock fragments ranges from $0.00 \%$ to $57.31 \%$. The lithic grains are commonly composed of quartz sandstones and siltstones. These fragments have originated from older sedimentary rocks from the basin basement (Fig. 10F). In particular, some clayey clasts represent intraformational provenance, such as lumps of clay (Figs. 10A, 11B). They are of an irregular shape caused by compaction under higher pressure (Fig. 10A, B). In other cases, coherent aggregates of sand, silt and clay are present. They were syndeposited with various "hard" components, such as quartz grains. According to Tucker (2001), this type of lithic grain is formed within the sedimentation area, derived from erosional reworking of previously deposited sediments.
The content of mica ranges from about $0.00 \%$ to $3.63 \%$. This mineral group is identified by elongated crystals, cleavage, typical colours and light extinction under crossed polars (Figs. 10D, 11A). Mica grains are strongly alternated and replaced by clay, iron oxides, or sericite.

The content of other minerals, including heavy minerals ranges from about $0.00 \%$ to $3.36 \%$. In particular, hematite cements are very common in the investigated rocks. The mineral played a very important role in rock duration and caused consolidation in the Neogene formations. Hematite may also be an excellent indicator for the reconstruction of palaeoclimate conditions. According to the clasification of Zuffa (1980), all samples are built of non-carbonate extrabasinal grains. Non-carbonate intrabasinal components (NC1) are extremely rare in the investigated samples, and represent clayey clasts, which were supplied from layers of clay within the basinal area.

The results of thin-section analysis of the $\mathrm{Ne}$ ogene rocks show that the sandstones belong to wackes (Fig. 9A), based on the classification of Pettijohn et al. (1987). They are sub-divided into quartz and lithic wackes (Tab. 4, Figs. 9A, 10, 11). However, based on the classification of Boggs (2009) they can be classified as quartz arenites, sublitharenites and litharenites (Fig. 9B).
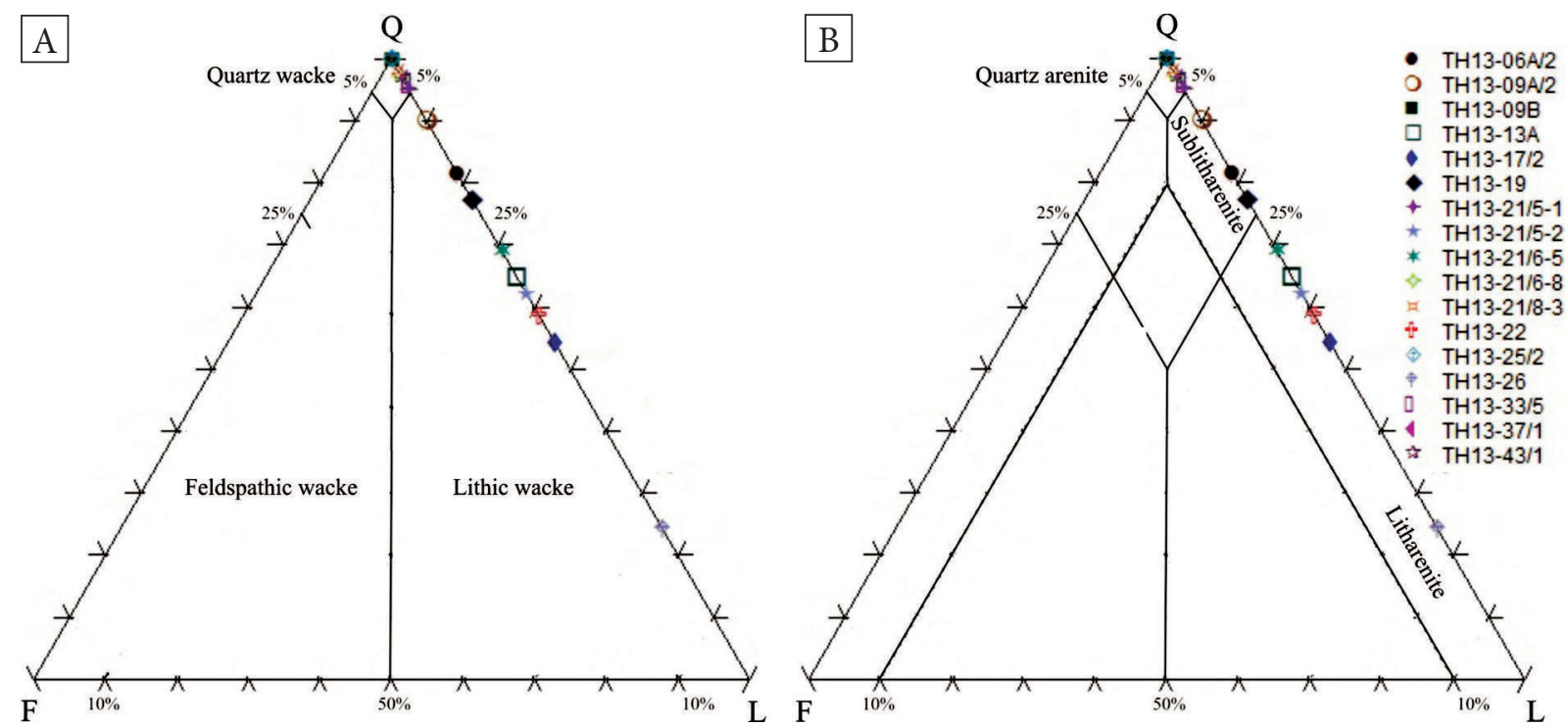

Fig. 9. Classification of sandstones: A) according to Pettijonh et al. 1987; B) according to Boggs 2009; Q-quartz, F-feldspar, $L$ - lithic clast 

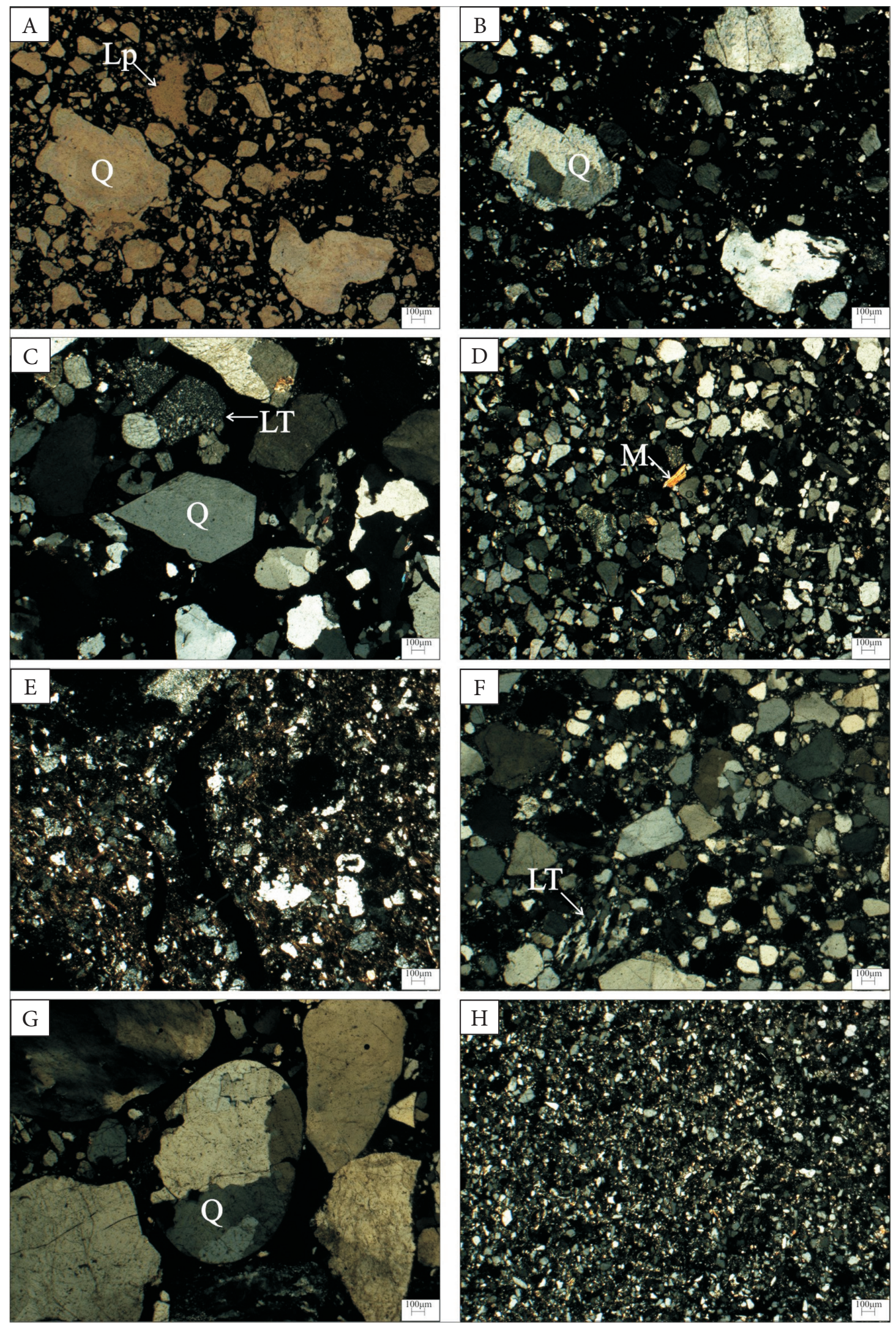

Fig. 10. Quartz wacke (Q - quartz, $L T$ - rock fragment, $M$ - mica, $L p$ - clayey intraclast): A), B) ferruginous cement and lumps of clay (LP) (TH13-17/1); C) mono- and polycrystal quartz and ferruginous cement (TH13-21/8-3); D) mica grains (TH13-33/5); E) quartz wacke, rich in organic matter (TH13-09A/2); F) metamorphic lithic grain (TH13-21/6-8); G) well-rounded quartz and lithic grains (TH13-21/5-2); H) quartz siltstone (TH13-09B5) 

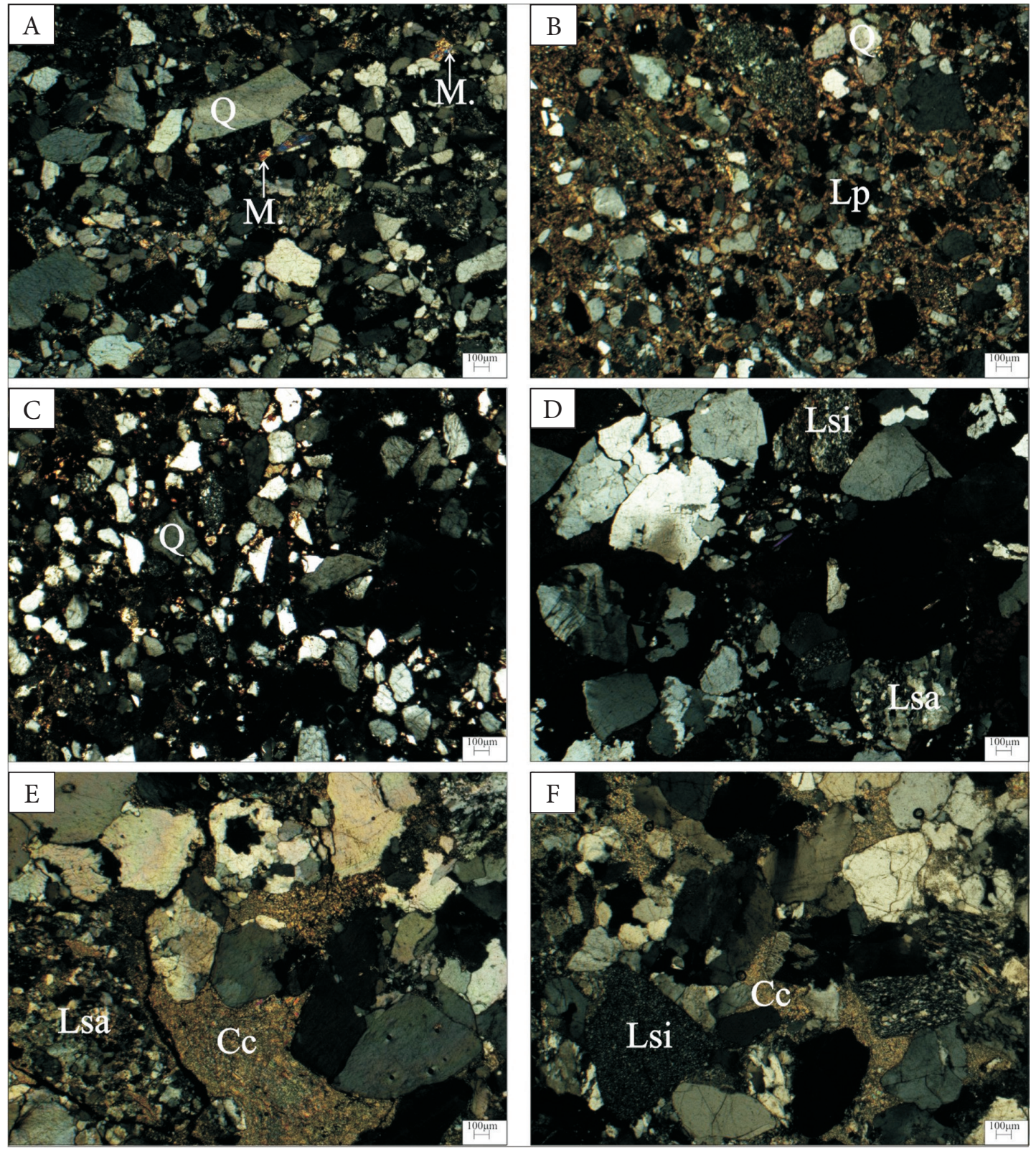

Fig. 11. Lithic wackes (Q - quartz, Lsa - sandstone clast, Lsi - siltstone clast, $M$ - mica, Lp - clayey intraclast, Cc - carbonate cement): A) strongly altered mica (TH13-21/6-5); B) clayey intraclasts (TH13-09A/2); C), D) lithic grains of sandstones and siltstones (TH13-06A/2, TH13-13A); E), F) carbonate cement (Cc) (TH13-26, TH13-17/2)

Quartz wackes were recognized in the Troi and $\mathrm{Ha}$ Khau sections, and adjacent to the Dong Ho area (Tab. 4). They belong to the Tieu Giao Formation. The hand specimens are purple or brown, and well lithified. They build sand bodies with a massive structure and different kinds of bedding, from isoclinal cross-bedding to horizontal bedding. They are interbedded with thin layers of conglomerates in the Troi and Ha Khau sections. The quartz wackes are composed of detrital quartz grains (31.41-66.98\%), mica (0.00-0.96\%), lithic grains $(0.00-2.87 \%)$, other minerals $(0.00-$ $0.49 \%)$, and matrix plus cement (29.19-68.59\%) (Tab. 4). Grains are very angular to sub-angular, poorly- to moderately sorted. Clasts and matrix consists mainly of quartz. Mica is strongly alternated (Fig. 10D). Cement is mainly iron-oxide.

A half of the samples represent lithic wackes (Tab. 4). They belong to the Tieu Giao and Dong Ho Formations. The hand specimens are purple and brown, and well lithified. They are massive or bedded, especially trough cross-bedded. They 
are interbedded with claystones (TH13-06A) or conglomerates (TH13-13A, TH13-17/2). The lithic wackes are composed of detrital quartz (18.39$50.25 \%)$, mica $(0.00-3.36 \%)$, lithic grains (5.56$57.31 \%)$, and matrix plus cement (20.78-57.34\%). Grains are very angular to sub-angular, poorlyto moderately sorted. The dominant component of clasts and matrix is still quartz, however, the lithic grains occur at more than $15 \%$ in the total content of Q, F and L. Mica is strongly alternated (Fig. 11A). Cement is mainly built of iron-oxide, clay or carbonate mud.

\section{PROVENANCE INTERPRETATIONS}

\section{Source area for coarse-grained lithic clasts}

Results of the coarse-grained lithic clast investigations (Tab. 1, Figs. 5, 6) show that the basement of the basin is built of polymictic conglomerates of the Hon Gai Formation. This is the source of rocks for the Neogene of the western and north-western parts of the Hoanh Bo Basin, whereas the Permian carbonate rocks of the Cat $\mathrm{Ba}$ Formation are exposed in the north and north-east of the basin (Fig. 12D). In exposure TH13-09, the black grey limestone clasts were delivered from the Permian limestones of the Cat Ba Formation. The clasts of quartzitic conglomerates and sandstones in exposures TH13-08 and TH13-22 (Fig. 12A, B) are from the lower members of the Hon Gai Formation; and the quartzitic siltstone clasts (exposures TH13-10 and TH13-19; Fig. 12C) are from the upper members of the Hon Gai Formation. This is why the differences in the clast composition among the particular outcrops are interpreted as strictly depending on the distribution of the basement rocks of the Hon Gai and Cat Ba Formations. Presently, we can observe the valley, which separates the carbonate formations and the Hoanh Bo Basin. However, during the Neogene period, the vertical drop of this valley was not as deep as it is nowadays. In exposure TH13-09 (Le Loi section), the sedimentary structures and facies represent alluvial fans. The process of physical weathering of carbonate rocks had caused the influx of clastic material. The debris had been debouched into the lake basin via alluvial fans (Tha et al. 2015, Tha 2016).
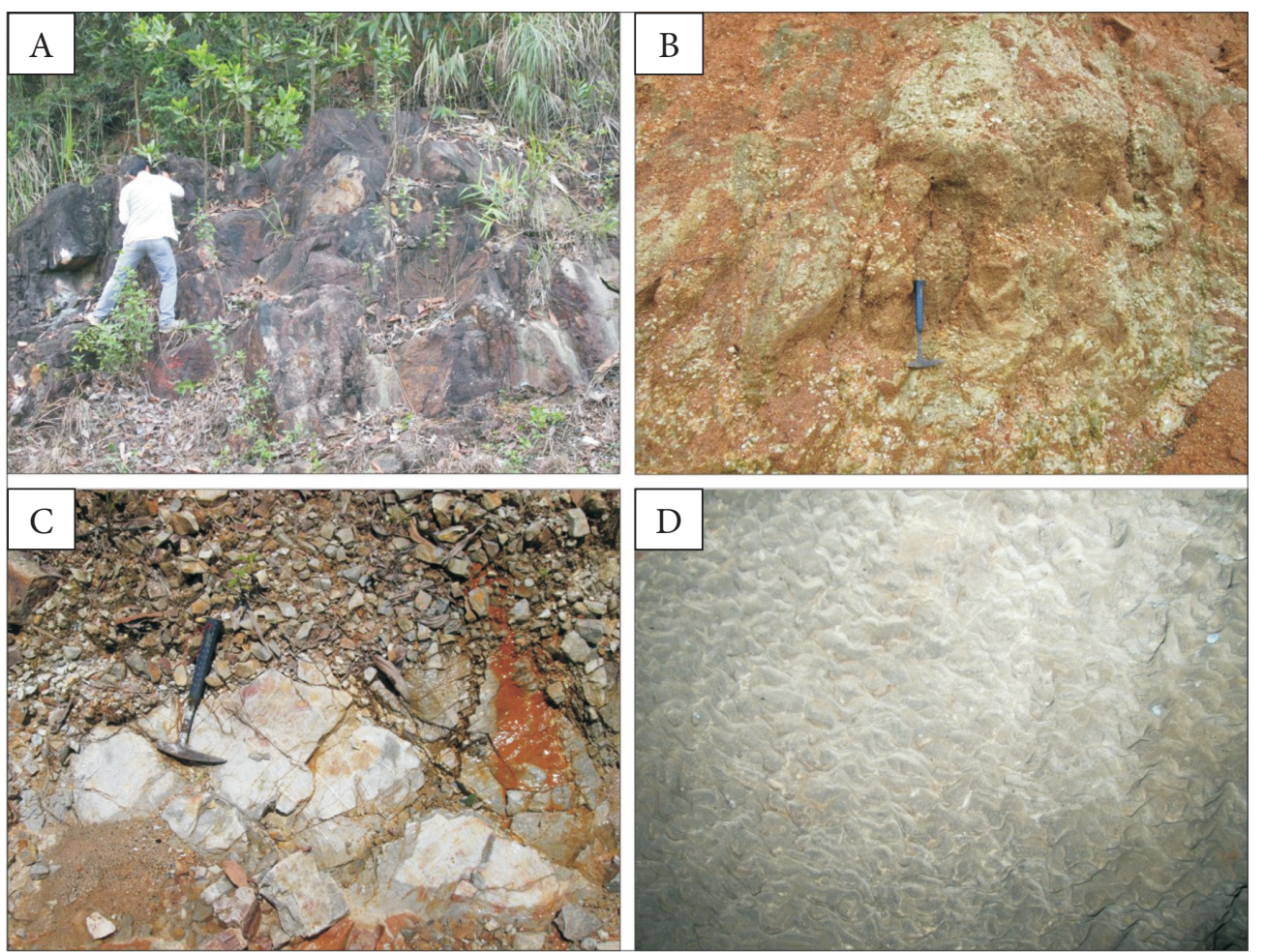

Fig. 12. Basement rocks of the Hoanh Bo Basin: A) quartzitic conglomerates and sandstones of the Hon Gai Formation (W part of the Hoanh Bo Basin, exposure TH13-22); B) quartz conglomerate of the Hon Gai Formation (N part of the Hoanh Bo Basin, exposure TH13-08); C) quartz siltstones of the Hon Gai Formation and quartz veins (NE part of the Hoanh Bo Basin, exposure TH13-19); D) limestones of the Cat Ba Formation (N part of the Hoanh Bo Basin, near exposure TH13-09) 
Based on the composition of lithic clasts, three groups of rock fragments have been recognized: monomictic (monomineral), oligomictic, and polymictic conglomerates (breccias). The term polymictic conglomerate is commonly used in the classification of conglomerates (breccias), when the sediment is composed of many types of lithic clasts such as metamorphic, igneous and sedimentary clasts. In the study area, lithic clasts comprise quartz and sedimentary fragments only. However, the conglomerates (breccias) in the study area are characterized by different sedimentary lithic clasts, such as carbonate rocks and/or extremely hard quartz siltstone fragments. This is the reason why they have been termed herein as polymictic conglomerates. The polymictic conglomerates (breccias) are the most common and have been encountered in all exposures, composing either matrix-supported conglomerates (breccias) or clast-supported conglomerates (breccias).
The quartz and quartzitic clasts were derived from rocks of the Hon Gai and Ha Coi formations. The quartz clasts are predominantly sub-rounded to well-rounded pebbles, white and grey in colour. Their shape is mostly prolate, bladed and rod-like. On the other hand, the conglomerates contain also sandstone pebbles cut by quartz veins. These imply that the quartz has mainly originated from the quartz veins within older rocks. The process of physical weathering of the sedimentary rocks (Hon Gai and Ha Coi formations) had broken such veins. They were redeposited many times in the sedimentary environment in the past, finally in the Neogene formations of the Hoanh Bo Basin.

For both the matrix-supported and clast-supported conglomerates, the presence of fractured clasts with common preferred orientation is typi$\mathrm{cal}$. The fractures usually appear as joints and normal faults (Fig. 13). The rock bodies are also cut by many small faults running parallel to the Trung Luong Fault.
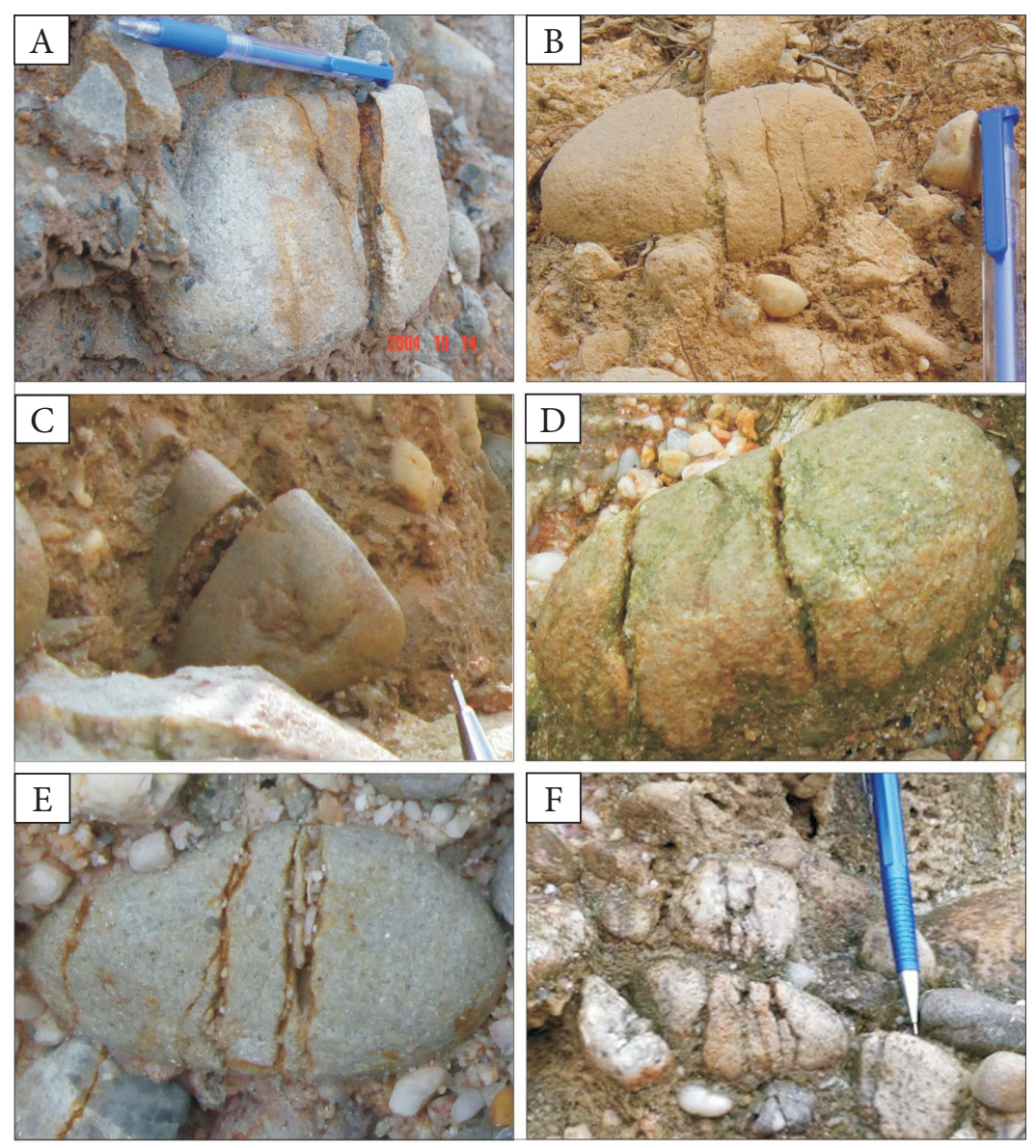

Fig. 13. Fractured pebbles from the Hoanh Bo Basin: A)-C) fractures with displacement (photos by Cuong N.Q, TH13-36); D)-F) fractures without displacement (joints) (TH13-35, TH13-39) 


\section{Source area for arenites}

Arenites are the major component, represented by a majority of very friable to friable, even unconsolidated rocks. Quartz arenites occur in the Troi, Gieng Day, and Ha Khau sections. These rocks show a wide range of grain sizes. Medium-grained sandstones are widespread over a large area. They are white in colour, and sometimes pinkish, salmon-coloured, purple, or light-yellow streaks caused by the staining by ferric oxides are visible. They do not contain a significant volume of carbonate grains or cements. Whereas, wackes are not the most common rocks in the study area. They occupy only a small part of the sedimentary succession.

The composition of the arenites and wackes is quite simple and differs only in the content of rock fragments. This is a great difference in comparison with other Neogene rocks in Vietnam. In the Hoanh Bo Basin, the Neogene deposits are composed of very angular to sub-rounded grains, poorly- to moderately sorted. Such features are typical of wackes (Richard 2000, Tucker 2001). Moreover, in this area, coherent aggregates of grains (sand, silt and clay), rock fragments and intrabasinal mud fragments commonly appear (Figs. 10A, B, 11B). This suggests that the source of sedimentary material was really close and the sediments were transported only over a short distance. Wackes are not environmentally restricted and commonly deposited within terrestrial basins, or on continental margins, or even by turbidity currents in relatively deep-water zones (Dżułyński \& Walton 1965, Tucker 2001). They commonly occur in flysch successions. However, wackes in the study area are typically red and red-brown in colour due to the impregnation of the clayey matrix by red ferric oxides (Figs. 10, 11). According to Richard (2000), such character of wackes is commonly found in alluvial, fluvial and deltaic environments. Besides, all sedimentological features allow to distinguish fluvial and lacustrine wackes. Fluvial quartz wackes occur within the conglomeratic bodies, whereas the lacustrine quartz wackes are lithic wackes interbedding layers of shales, claystones, and siltstones.

\section{CONCLUSIONS}

The study of the Neogene sedimentary sequence from the Hoanh Bo Basin (Quang Ninh province,
NE Vietnam) has revealed the following results. The Hoanh Bo Basin is infilled with terrestrial sediments, composed mainly of conglomerates, sandstones, siltstones, claystones and shales. The conglomerates and sandstones are poor in composition and texturaly immature. They are composed of mainly quartz and sedimentary rock fragments, and a small amount of mica plusing minerals. Cement is mainly built of iron-oxide, clay or carbonate mud, but iron-oxide plays decisional role in diagenesis. The source area for the Hoanh Bo Basin sediments was located in the close vicinity of the basin. It was built of strongly weathered rocks of the Hon Gai, Ha Coi, Cat Ba Formations.

The field work was mainly supported by the Faculty of Geology, University of Warsaw (Poland), the Institute of Geological Sciences (VAST) and partly by the project No.105.01-2014.38 (Vietnam).

\section{REFERENCES}

Boggs S.Jr., 2009. Petrology of sedimentary rocks. Cambridge University Press.

Dickinson W.R. \& Suczek C.A., 1979. Plate tectonics and sandstone compositions: American Association of Petroleum Geologists Bulletin, 63, 2164-2182.

Dickinson W.R. \& Valloni R., 1980. Plate settings and provenance of sands in modern ocean basins. Geology, 8, $82-86$.

Dovjikov A.E (ed.), 1965. Geology of North Viet Nam. General Department of Geology and Minerals of Vietnam, Hanoi.

Dzanh T., 1995. Stratigraphic correlation of Neogene sequences of Vietnam and adjacent areas. Journal of Geology, Hanoi, B/5-6, 114-120.

Dżułyński S. \& Walton E.K., 1965. Sedimentary features of flysch and greywackes. Elsevier Publishing Company, Amsterdam.

Folk R.F. \& Ward W.C., 1957. Brazos River bar, a study in the significance of grain-size parameters. Journal of Sedimentary Petrology, 27, 3-26.

Huyen D.T. (ed.), 2007. Stratigraphy of Phanerozoic deposits in the Dong Bac Bo (NE). Report, Vietnam Institute of Geosciences and Mineral Resources.

Ingersoll R.V \& Suczek C.A., 1979. Petrology and provenance of Neogene sand from Niconbar and Bengal Fans, DSDP sites 211 and 218. Journal of Sedimentary Petrology, 49, 1217-1228.

Johsson M.J. \& Basu A. (eds.), 1993. Processes Controlling the composition of clastic sediments. Geological Society of America Special Paper, 284, Geological Society of America, Boulder, CO.

Khuc V. \& My B.P. (eds.), 1988. Geology of Vietnam, Part I: Stratigraphy. General Department of Geology and Minerals of Vietnam, Hanoi. 
Khuc V., 2001. New discover about stratigraphy of Jurassic sediments in Vietnam collecting in 6 years (1994-1999) and their signification. Journal of Geology, Hanoi, A/263, 6-22.

Ky H.N. (ed.), 1999. Geology and mineral resources of the Hai Phong Map sheet, with the Geological Map of the Ha Long Sheet at 1:200,000 scale. General Department of Geology and Minerals of Vietnam, Hanoi.

Liem N.V., 1985. Late Paleozoic in Vietnam. Science and Technology Publishing House, Hanoi.

Luong N.C. (ed.), 1999. Geology and mineral resources of the $\mathrm{Ha}$ Long Map sheet, with the Geological Map of the Ha Long sheet, 1:200,000 scale. General Department of Geology and Minerals of Vietnam, Hanoi.

Mack G.H., 1984. Exceptions to the relationship between plate tectonics and sandstone compositions. Journal of Sedimentary Petrology, 91, 1-21.

Morton A.C., Todd S.P., Haughton P.D.W., 1991. Developments in sedimentary province studies. Geological Society of London Special Publication, 57, Geological Society Publishing House, Bath.

Nhan T.D. \& Danh T., 1975. The new discovers about biostratigraphy of the Neogene sediments in the east of Bac Bo. [in:] Nhan T.D. \& Danh T. (eds.), Stratigraphic Works, Science and Technology Publishing House, Hanoi, 244-283.

Patte E., 1927. Etudes géologiques dans I’Est du Tonkin. Bulletin du Service géologiques de I'Indochinhe, 16, 1, 1-332.

Pettijohn F.J., Potter P.E. \& Siever R., 1987. Sand and sandstones. $2^{\text {nd }}$ ed. Springer-Verlag, New York.

Quang P.V., 1969a. The age of the coal-bearing deposits Hon Gai and the development of regional geology in Mesozoic. Journal of Geology, Hanoi, 13-39.

Quang P.V. (ed.), 1969b. Geological and Mineral resources for the coal basins in the northeast of Bac Bo (Quang Ninh) of Vietnam, scale 1:200,000. Report, General Department of Geology and Mineral of Vietnam, Hanoi.

Richard C.S, 2000. Applied sedimentology. Academic Press, London.

Sun D., Bloemendal J., Rea D.K., Vandenberghe J., Jiang F., An, Z. \& Su R., 2002. Grain-size distribution function of polymodal sediments in hydraulic and aeolian environments, and numerical partitioning of the sedimentary components. Sedimentary Geology, 152, 263-277.

Suttner L.J., 1974. Sedimentary petrofraphic provinces: an evaluation. [in:] Ross C.A (ed.), Paleogeographic Provinces and Provinciality, Society of Economic Paleontologists And Mineralogists Special Publication, 21, 75-84.

Syvitski J.P.M. (ed.), 1997. Principles, Methods and Application of Particle Size Analysis. Cambridge University Press, Cambridge.

Tha H.V., 2016. Reconstruction of depositional environments in the Hoanh Bo Basin (Neogene, Quang Ninh Province, Vietnam) [PhD thessis, unpublished].

Tha H.V., Wysocka A., Pha P.D., Cuong N.Q \& Ziółkowski P., 2015. Lithofacies and depositional environments of the Paleogene/Neogene sediments in the Hoanh Bo Basin (Quang Ninh province, NE Vietnam). Journal of Geology, Geophysics and Environment, 41, 353-371.
Tha H.V., Wysocka A., Pha P.D., Cuong N.Q., Bac D.T., Ziółkowski P. \& Quang N.M., 2014. Lithofacies and depositional environments of the Neogene sediments in the Hoanh Bo Basin (Quang Ninh province - NE Vietnam). [in:] Book of Abstracts The First International Conference "Scientific-research Coorperation between Vietnam and Poland", AGH University of Technology, Kraków, 45.

Thanh T.D. \& Khuc V., 1995. Stratigraphy of Vietnam: Volume 3. Science and Technology Information Center, Ha Noi.

Thanh T.D. \& Khuc V., 2009 (eds). Stratigraphic units of Vietnam. Vietnam National University Publishing House, Hanoi, 526 pp.

Torres V., Vandenberghe J. \& Hooghiemstra H., 2005. An environmental reconstruction of the sediment infill of the Bogota' basin (Colombia) during the last 3 million years from abiotic and biotic proxies. Journal of Palaeogeography, Palaeoclimatology, Palaeoecology, 226, 27-148.

Tri T.V. \& Khuc V., 2009 (eds). Geology and Natural Resources of Vietnam. Natural Science and Technics Publishing House, Hanoi.

Tri T.V., 1977 (ed.). Geology of Viet Nam: The north part. Science and Technology Publishing House, Hanoi.

Tru V., Diep V.N., Quan H.Q., Hung L.T. \& Hien L.V., 2002. Research on evaluation of oil shale potential in the Hoanh Bo Trough, Quang Ninh Province, Vietnam. Report, Vietnam Petroleum Institute, Hanoi.

Trung P.Q., Bat D., An N.Q., Khoi D.V. \& Hieu D.V., 1999. The new documentation of spore and pollen fossil in the Dong Ho Formation. Journal of Petroleum Geology, Hanoi, 3, 2-8.

Tucker M.E., 2001. Sedimentary Petrology. Blackwell Science, Oxford.

Tuyen T.T. et al. (ed.), 1995. Geological and Mineral resources Map for group sheets Binh Lieu-Mong Cai, scale 1:50,000. Report, General Department of Geology and Minerals of Vietnam, Hanoi.

Uy N.D., 1995. Geological investigation in the Ha Long city. Report, Vietnam Institute of Geosciences and Mineral Resources, Hanoi.

Valloni R. \& Mezzadri G., 1984. Compositional suites of terrigenous deep-sea sands of the present continental margins. Sedimentology, 31, 353-364.

Wysocka A. \& Świerczewska A., 2005. Tectonically-controlled sedimentation of Cenozoic deposits from selected basins along the Vietnamese segment of the Red River fault Zone. Acta Geologica Polonica, 55, 131-145.

Wysocka A. \& Świerczewska A., 2010. Lithofacies and depositional environments of Miocene deposits from tectonically-controlled basins (Red River Fault Zone, northern Vietnam). Journal of Asian Earth Sciences, 39, 109-124.

Zuffa G.G., 1980. Hybrid arenites: their composition and classification. Journal of Sedimentary Petrology, 50, 21-29.

Zuffa G.G., 1985 (ed.). Provenance of arenites. Reidel, Dordrecht.

Zuffa G.G., Normark W.R. \& Brunner C.A., 1995. Arenite petrography in sequence stratigraphy. Journal of Geology, 103, 451-459. 